\title{
Marie-Claire Bergère, Shanghai: China's Gateway to Modernity
}

Translated by Janet Lloyd, Stanford, CA, Stanford University Press, 2009, $520 \mathrm{pp}$.

\section{Jeffrey Wasserstrom}

\section{(2) OpenEdition}

\section{Journals}

Electronic version

URL: http://journals.openedition.org/chinaperspectives/5478

DOI: 10.4000/chinaperspectives.5478

ISSN: 1996-4617

\section{Publisher}

Centre d'étude français sur la Chine contemporaine

\section{Printed version}

Date of publication: 1 January 2011

Number of pages: 87-88

ISSN: 2070-3449

\section{Electronic reference}

Jeffrey Wasserstrom, "Marie-Claire Bergère, Shanghai: China's Gateway to Modernity », China Perspectives [Online], 2011/1 | 2011, Online since 30 March 2011, connection on 23 September 2020. URL : http://journals.openedition.org/chinaperspectives/5478; DOI : https://doi.org/10.4000/ chinaperspectives.5478

This text was automatically generated on 23 September 2020.

(c) All rights reserved 


\section{Marie-Claire Bergère, Shanghai: China's Gateway to Modernity}

Translated by Janet Lloyd, Stanford, CA, Stanford University Press, 2009, $520 \mathrm{pp}$.

Jeffrey Wasserstrom

2008 was unquestionably Beijing's year, in terms of both spectacle and publishing. That was when, of course, the city hosted China's first Olympics, an extravaganza that began with a big-budget opening Ceremony that focused largely on historical themes but was held in one of the state-of-the-art new stadiums that have helped make parts of the capital look futuristic. There was a comparable temporal eclecticism, a mixing of historical and present-minded themes, in the wide range of Beijing books published that year, many of which were aimed at reaching that elusive intellectually curious Western reader who is interested in knowing more about China. Some focused purely on the city's Olympic present and threw in for good measure comments on where the metropolis might

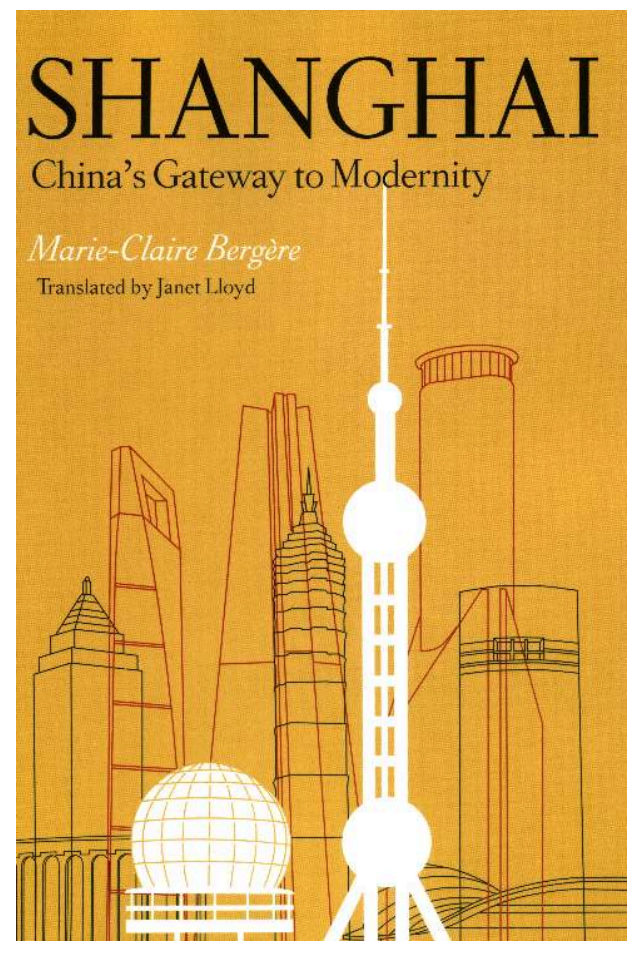
be headed. Others, however, looked back to earlier times, connecting previous incarnations of China's capital (as the home to emperors, then warlords, then Mao) to its contemporary situation as a place that is home to both grandiose historic structures, such as the Forbidden City, and space-age pieces of architecture, such as the controversial CCTV building designed by Rem Koolhaas and the Bird's Nest Stadium (above which fireworks exploded and in which 
drummers drummed on 08/08/08). The intensive international media coverage of the Games, combined with this Beijing-focused book boom, did a great deal to alter global images of the metropolis, which had previously been associated almost exclusively with political venues (such as Tiananmen Square) and historic sites (in most cases tied to the dynastic past).

2 So far, at least, even though Shanghai has hosted a sequel to the Games (the World Expo was touted in the Chinese press as an economic and technological "Olympics"), 2010 has not turned out to be that city's year in the same sense or at least to the same degree. It is true that the Expo, which opened on May Day and closed at the end of October, turned out to be, as planned, the biggest event of its kind in history, having a larger footprint and attracting more visitors (over 70 million) than even the most ambitious nineteenth-century World's Fair (such as the great Parisian Universal Expositions) and the most expensive twentieth-century World Expos (such as the 1970 one in Osaka that was the previous holder of the total attendance record due to the 64 million visitors it drew). Still, as important as the extravaganza was for domestic audiences (the vast majority of visitors to the Shanghai fairground were Chinese nationals), in terms of attracting international media attention and altering global ideas about the host city, the 2010 Expo was no match for the 2008 Games. For people living outside of China, Shanghai's reputation is not so different now (I write this in November 2010) from what it was a year ago. Before the Expo opened for business, after all, Shanghai was already seen as a hot tourist destination, a thriving business and shopping hub, and a metropolis with elements that spoke to both a colourful past and a futuristic present.

3 Turning to publishing, there is also a clear contrast between Beijing's Olympic year and Shanghai's Expo year. Some interesting books about the city have certainly appeared during 2010, but this simply continues a long-term pattern, for intriguing Westernlanguage works on Shanghai, including many aimed at general readers, have been coming out fairly steadily for a couple of decades now. Even in Beijing's year of 2008, some unusually interesting, accessibly written works on the capital's rival city were issued that competed for the attention of non-specialist readers. These included Lynn Pan's elegantly crafted and beautifully produced Shanghai Style: Art \& Design Between the Wars (Hong Kong, Joint Publishing, 2008); Nick Land et al.'s Urbanatomy: Shanghai 2008 (Shanghai, Urbanatomy, 2008), a difficult-to-categorise work (part guide book, part foray into urban theory) for which I was one of many contributors; and, at the more academic end of the spectrum running from specialist to general interest works, Wenhsin Yeh's ambitious collection of essays on the city's first period of engagement with global capitalism, Shanghai Splendor: Economic Sentiments and the Making of Modern China, 1843-1949 (University of California Press, 2008).

4 Still, even if 2010 has been a relatively ordinary year for the publication of new books about Shanghai, it has been an important one for translations of previously available work into English. This is because the year began with Stanford University Press issuing the much-anticipated English-language edition of Marie-Claire Bergère's wide-ranging, gracefully written, and thoroughly researched survey of the city's past. For more than half a decade, when people who want to get a sense of the sweep of Shanghai's modern history have asked me where to start, I have told them that while an enormous amount has been published in Chinese, English, and Japanese, the most satisfying general overview of the local past that discussed the storied treaty-port century (1843-1943), 
the Civil War years (1945-1949), the Mao period (1949-1976), and also the Reform period (1979- ) was only available in French. There were many fine introductions to the story of Shanghai's rise from a walled city of a couple hundred thousand inhabitants in the 1830s (it was not then, as the oft-repeated legend would have it, a mere "fishing village") to one of the largest and most complexly internationalised urban centres in the world in the 1930s. And some works in languages other than French had tried via epilogues (the strategy used by Yeh in Shanghai Splendor) or other techniques (e.g., in my own 2009 Routledge book, Global Shanghai, through "snapshots" of several individual years, 1950, 1975, and 2000) to connect the city's pre-1949 past and contemporary period. Until 2010, though, Histoire de Shanghai by Bergère, one of the doyennes of French Sinology, was in a class by itself as a lively synthetic work, based on the best scholarship in multiple languages, that took the reader through the city's multifaceted modern past in a decade-by-decade and sometimes year-by-year manner, without the stilted treatment of the post-1949 period that still tended to mar even the best works in Chinese.

Bergère was ideally suited to take on the challenge of bringing together into a coherent narrative the city's transformation from a unified Chinese urban centre (prior to 1843), to a subdivided treaty port (with three separate districts, two of them foreign-run, each governed in a distinctive way), to a socialist and now arguably post-socialist metropolis (albeit one still run by a Communist Party). She is a scholar who has long been passionately interested in the history of the Chinese bourgeoisie and in Shanghai, which more than any other mainland city has been identified with the inroads into China before and after 1949 of international capitalism and global fashions and patterns of consumption. She is also someone who, throughout her long career, has shifted easily from writing for scholarly venues, such as the path-breaking journal Annales, to penning synthetic works and surveys intended for lay readers and for students. Histoire de Shanghai was a welcome addition to the literature on the city when it first appeared, since it made the most of her deep knowledge of a single place and her narrative gifts, and it is a very good thing indeed that it is now available in English and that it reads so well in this language, thanks to the talents of the gifted translator enlisted by Stanford, Janet Lloyd, whose previous credits include a fluid translation of Bergère's well-received biography of Sun Yat-sen.

There is much to admire about Shanghai: China's Gateway to Modernity, as the Englishlanguage edition is called. For the non-specialist, the clarity of the author's description of the complex political arrangements of the treaty-port era will be welcome, as will be Bergère's ability to capture the feel of particular moments in the city's past (her rendering of life in the metropolis during World War II is particularly compelling) and mix descriptions of economic developments with well-turned short character sketches of important capitalists, literary figures, and revolutionaries. For specialists, what stands out as most novel, aside from her determination to integrate discussion of the pre-Communist and Communist eras, is her close attention, in the treaty-port era chapters, to the French Concession. She does not overstate the importance of this district, which was never as large or as economically significant as the Britishdominated International Settlement that tends to get so much more attention in accounts of the period - indeed she stresses just how tiny the French Concession's population was in its first years. Still, she continually reminds us of the important differences between the Concession and the Settlement, and makes excellent use of archival documents, memoirs, and travel writings in French that other scholars of the 
city have often overlooked. The result is not a dramatically revisionist account, but one that is enlivened by colourful quotes and comments that come from people other than the usual literary and journalistic suspects.

7 I was left with just one major regret upon finishing the book: that it did not include an epilogue taking the story of the city from the turn of the millennium, when the French edition was completed, up toward 2010. Most of Bergère's main points about Shanghai's current trajectory remain valid. Still, it would have been very interesting to hear a scholar who spent her career studying Shanghai while teaching in France's capital reflect a bit on how the introduction of a metro system had changed, and the hosting of a Universal Exposition with twenty-first century characteristics might change, the distant urban centre that has long prided itself on being a Paris of the East - and to have her reflect as well on whether, in an era when Beijing is riding high from its Olympic bounce, Guangzhou has the most daring journalists, and Hong Kong continues to play other roles that treaty-port Shanghai once performed, the days are gone forever when any city could be China's sole "gateway to modernity."

\section{AUTHOR}

\section{JEFFREY WASSERSTROM}

Professor of History and Chair of the Department at the University of California, Irvine. 